\title{
Prevalence of non-communicable diseases in Brazilian children: follow-up at school age of two Brazilian birth cohorts of the 1990's
}

\author{
Antônio A Silva ${ }^{1}$, Marco A Barbieri' ${ }^{2}$, Viviane C Cardoso ${ }^{2}$, Rosângela F Batista' ${ }^{1}$, Vanda M Simões ${ }^{3}$, Elcio O Vianna ${ }^{4}$, \\ Manoel R Gutierrez², Maria L Figueiredo', Nathalia A Silva', Thaís S Pereira', Juliana D Rodriguez', \\ Sônia R Loureiro ${ }^{5}$, Valdinar S Ribeiro ${ }^{6}$ and Heloisa Bettiol ${ }^{2^{*}}$
}

\begin{abstract}
Background: Few cohort studies have been conducted in low and middle-income countries to investigate noncommunicable diseases among school-aged children. This article aims to describe the methodology of two birth cohorts, started in 1994 in Ribeirão Preto (RP), a more developed city, and in 1997/98 in São Luís (SL), a less developed town.

Methods: Prevalences of some non-communicable diseases during the first follow-up of these cohorts were estimated and compared. Data on singleton live births were obtained at birth (2858 in RP and 2443 in SL). The follow-up at school age was conducted in RP in 2004/05, when the children were 9-11 years old and in SL in 2005/06, when the children were 7-9 years old. Follow-up rates were 68.7\% in RP (790 included) and 72.7\% in SL (673 participants). The groups of low (<2500 g) and high ( $\geq 4250 \mathrm{~g}$ ) birthweight were oversampled and estimates were corrected by weighting.

Results: In the more developed city there was a higher percentage of non-nutritive sucking habits $(69.1 \%$ vs $47.9 \%)$, lifetime bottle use (89.6\% vs $68.3 \%$ ), higher prevalence of primary headache in the last 15 days (27.9\% vs $13.0 \%$ ), higher positive skin tests for allergens (44.3\% vs $25.3 \%$ ) and higher prevalence of overweight (18.2\% vs $3.6 \%$ ), obesity ( $9.5 \%$ vs $1.8 \%$ ) and hypertension (10.9\% vs $4.6 \%$ ). In the less developed city there was a larger percentage of children with below average cognitive function (28.9\% vs $12.2 \%)$, mental health problems (47.4\% vs $38.4 \%)$, depression (21.6\% vs $6.0 \%$ ) and underweight (5.8\% vs 3.6\%). There was no difference in the prevalence of bruxism, recurrent abdominal pain, asthma and bronchial hyperresponsiveness between cities.
\end{abstract}

Conclusions: Some non-communicable diseases were highly prevalent, especially in the more developed city. Some high rates suggest that the burden of non-communicable diseases will be high in the future, especially mental health problems.

\section{Background}

Cohort studies seek to verify and evaluate the health of the population and provide scientific data on the etiology of diseases, allowing the establishment of important preventive measures. These studies are increasingly used to answer many questions about health risks to the population due to their ability to generate new knowledge related to various outcomes [1].

\footnotetext{
* Correspondence: hbettiol@fmrp.usp.br

${ }^{2}$ Departamento de Puericultura e Pediatria, Faculdade de Medicina de Ribeirão Preto, Universidade de São Paulo, Ribeirão Preto, SP, Brasil Full list of author information is available at the end of the article
}

Birth cohorts have the advantage of permitting the determination of health interferences suffered during the life cycle of an individual. They permit to understand the effects of exposures and experiences during intrauterine life and of childhood diseases on the future health of individuals, despite difficulty in obtaining data on exposure to early risk factors [2]. Classic examples are the studies of Barker, started in the 20th century, which related birth weight to mortality from chronic diseases in adults, such as cardiovascular disease and hypertension [3].

In Latin America there is an increased incidence of chronic non-communicable diseases [4]. However, many 
of the investigations of their possible etiologies, including studies conducted in Brazil [5], dealt only with risk factors acting in adulthood, following models of investigation such as the Framingham study [1].

In Brazil, the first longitudinal birth cohort study started in Ribeirão Preto, São Paulo State, in 1978/79. This research aimed to investigate the influence of socioeconomic conditions on perinatal health, human reproduction, infant mortality and medical care [6,7]. In 1982, the first birth cohort from Pelotas started and thereafter two other cohorts were initiated in 1993 and 2004 in this city [8]. In Ribeirão Preto, data from a new cohort of 1994 permitted comparisons with the 1978/79 cohort from the same city and with the 1997/98 São Luís cohort $[9,10]$.

Prevalence rates of obesity and mental health problems in children are high and increasing [11,12]. Despite the growing number of cohort studies in progress to assess prevalence of non-communicable diseases in childhood [13], few have estimated the prevalence of depression, below average cognitive function, atopy and bronchial hyperresponsiveness, especially in low and middle-income countries. In Brazil there is also little information on regional inequalities in relation to these problems.

This article aims to describe the methodology of a school age follow-up of two birth cohorts initiated in 1994 in Ribeirão Preto and in 1997/98 in São Luís. It also aims to estimate and compare prevalences of some non-communicable diseases during the first follow-up of these cohorts. Ribeirão Preto is more developed than São Luís. Contrasting socioeconomic conditions are interesting to analyze in view of possible differences in the prevalence of different conditions, given that these cities are going through different stages of the epidemiological transition.

\section{Methods}

\section{Study sites}

The study was based on two birth cohorts, one initiated in Ribeirão Preto in 1994 and the other in São Luís in 199798 , and on follow-up studies conducted in RP in 2004/05, when the children were 9-11 years old and in SL, in 2005/ 06, when the children were 7-9 years old. Ribeirão Preto is a city in the state of São Paulo, located in the Southeast, a rich and industrialized region. It had a population of 461,427 inhabitants in 1994 [9]. Its Municipal Human Development Index was 0.855 in 2000 [6]. São Luís is the capital of Maranhão state, located in the Northeast, one of the poorest regions of the country. It had a population of 781,068 inhabitants in 1997 [10]. Its Municipal Human Development Index was 0.778 in 2000 [6].

\section{Assessment at birth}

A total of 2923 infants born at 10 maternity hospitals of the city over a four-month period (April-August 1994) were included in the first stage of the Ribeirão Preto cohort study, representing $99 \%$ of all live births. Losses represented less than $5 \%$ of all births. Excluding twins, the final sample consisted of 2858 births to residents of the city [9].

The first phase of the São Luís cohort study was conducted from March 1997 to February 1998, using systematic sampling stratified by the number of births at 10 public and private maternity hospitals in the city. In each hospital one out of seven children was randomly selected, including 2541 hospital births (live births, stillbirths and singletons or multiple births of mothers living in the city). The sample was representative of births in the city because hospital births accounted for $96.3 \%$ of the total. After exclusion of multiple births $(n=50)$ and stillbirths ( $\mathrm{n}=48$ ), the final sample consisted of 2443 births. Losses due to refusal or inability to locate the mother occurred in $5.8 \%$ of cases [10].

In the two cohorts, anthropometric data and information on pregnancy, childbirth and postpartum were collected at birth through a standardized questionnaire answered by the child's mother.

\section{Follow-up study of schoolchildren}

Five birth weight groups were considered for the followup study: very low birth weight (VLBW $<1500 \mathrm{~g})$, low birth weight (LBW -1500 to $<2500 \mathrm{~g}$ ), insufficient birth weight ( 2500 to $<3000 \mathrm{~g}$ ), normal birth weight (3000 to $<4250 \mathrm{~g}$ ), and children whose birth weight was at least two standard deviations above the population mean, who were classified as high birth weight (HBW $\geq 4250$ g). The students in these weight groups with a smaller number of infants (VLBW, LBW and HBW) were oversampled in order to increase the study power.

Children were traced at schools, or using the addresses supplied by the mother at birth and by media advertising. All parents or guardians of children in the groups of VLBW, LBW and HBW and a fraction of one out of three children in the groups of normal and insufficient birth weight were eligible and were invited to participate by telephone or mail. In Ribeirão Preto, after excluding deaths in the first year of life $(n=48), 1150$ children were eligible for follow-up. The follow-up rate was $68.7 \%$ (169 LBW, $28 \mathrm{HBW}$ and 593 normal and insufficient birth weight). A total of 790 children participated in the follow-up (Figure 1). In São Luís, excluding 65 deaths in the first year, 2378 children were alive at one year of age. Thus, 673 of 926 eligible children participated in the follow-up study $(72.7 \%$ of the original target group, 81 being LBW, $19 \mathrm{HBW}$ and 573 being of normal and insufficient birth weight) (Figure 2). Followup losses occurred due to migration, impossibility to locate the children, children not enrolled in school, and school or parental refusal. 


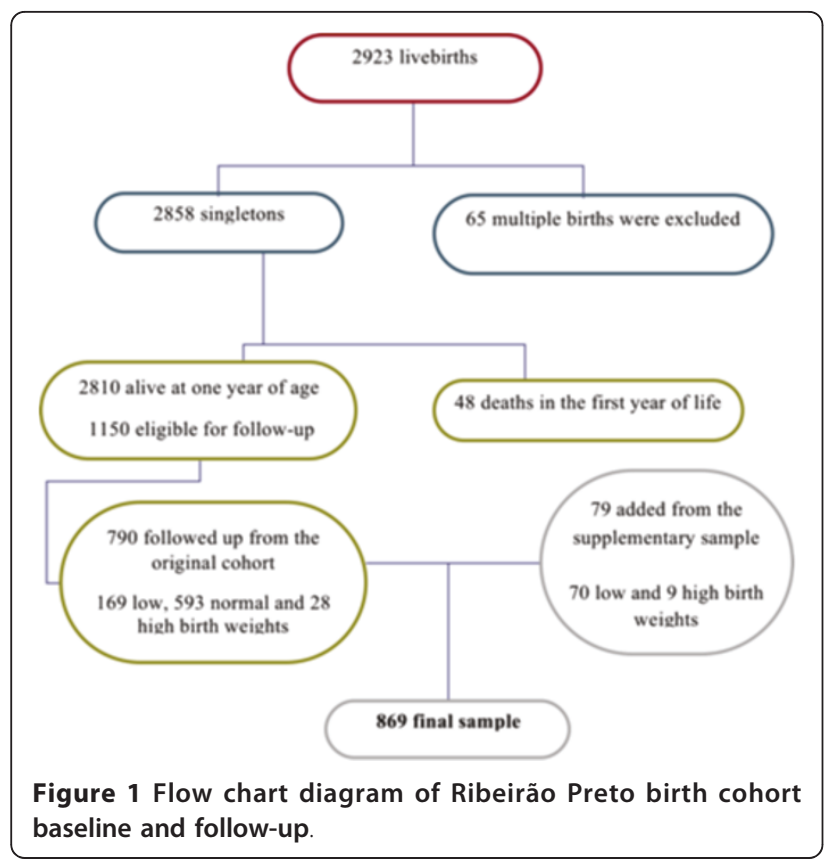

\section{Additional sample}

Since mortality was very high among children weighing less than $1500 \mathrm{~g}$ and $\geq 4250 \mathrm{~g}$, a non-random additional sample was recruited, for a total of 132 children in SL and 79 in RP. Only children whose birth weights and gestational ages could be confirmed by inspecting hospital records or child health cards were included. Thus, the total sample included 1674 children, 869 from RP (Figure 1) and 805 from SL (Figure 2). The additional sample will only be included in selected studies to test

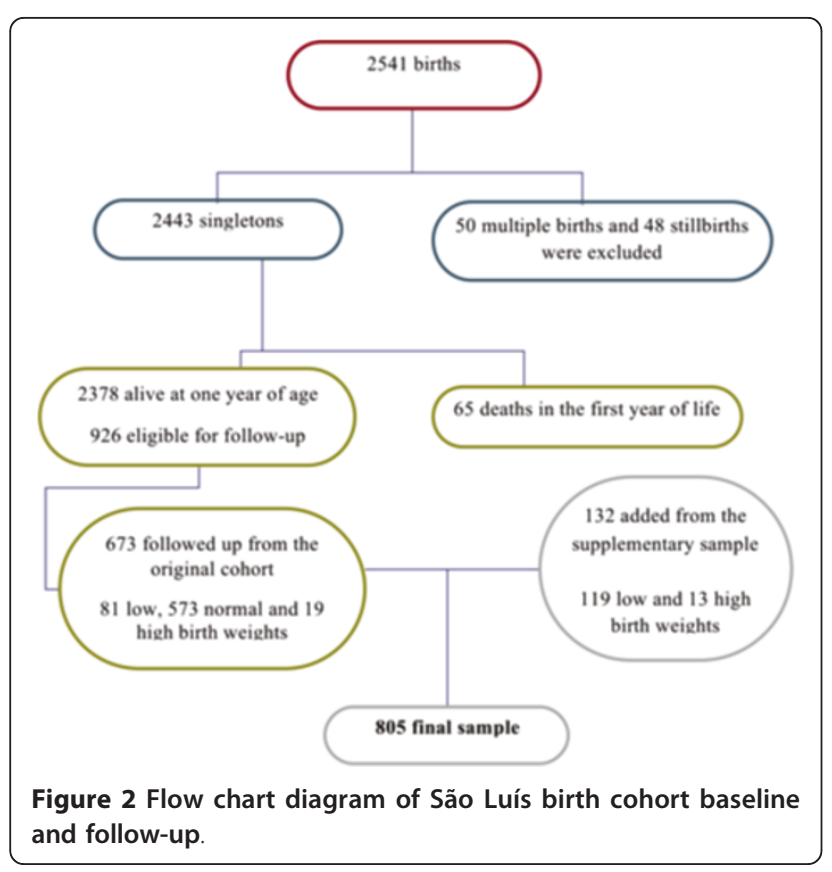

hypotheses concerning groups of very low and high birth weight.

\section{Sample size and study power}

A sample of 673 children (SL) and 790 (RP) has a 90\% power to detect a minimum difference of $10 \%$ in the prevalence of the different conditions studied (estimated at about $50 \%$, which is the prevalence that yields the maximum sample size) between the exposed and unexposed groups, with a $5 \%$ probability of type I error.

\section{Data Collection}

A standardized questionnaire was applied to parents or guardians of children from the two cohorts, containing demographic questions and questions regarding general and oral health of the children. The questionnaire included variables concerning bruxism, nonnutritive sucking habits, recurrent abdominal pain and daily time spent in some sedentary activities. Cognitive function, mental health problems and childhood depression were also evaluated. Anthropometric examination was performed, and weight and height were measured. The questionnaire administered by the International Study of Asthma and Allergies in Childhood (ISAAC), translated and validated to assess asthma symptoms, was applied [14]. The assessment of asthma, bronchial hyperresponsiveness (methacholine challenge test) and skin tests for allergens was performed in a non-random subsample drawn by convenience. For each child of low birth weight two children of normal birth weight were included. The subsample included 328 children in RP and 330 in SL, corresponding to $41.5 \%$ and $49.0 \%$ of the original samples, respectively.

\section{Assessment of cognitive function}

We used the Raven Colored Progressive Matrices Test, standardized for Brazilian children, which assesses general aspects of nonverbal intelligence, based on the multifactorial theory of Spearman [15]. It consists of five sets of 12 problems to infer the relationship between matrices. The sum of correct responses provides the overall score. It does not require reading and writing skills. The most satisfactory method of interpreting the overall score is by calculating the person's percentile by comparing his/her score to that attained by people of the same age and by identifying his/her relative position. This method makes no a priori assumption that the development of intellectual capacity is necessarily uniform or symmetrically distributed in childhood [15]. We calculated the prevalence of cognitive function below average or considered poor ( $\leq 25$ percentile).

\section{Human figure drawing (HFD)}

This is a maturity assessment that takes into account evolutionary and emotional indicators present in graphic 
production. It is also an indicator of cognitive development. It has been standardized by Wechsler in Brazil [16] and involves a simple activity - the drawing of a person using pencil and eraser. The standardized scores are converted to percentiles. We calculated the prevalence of below average, borderline or poor (below the 25th percentile) HFD.

\section{Mental health problems}

The Strengths and Difficulties Questionnaire (SDQ) was proposed by Goodman in 1997 [17] for screening behavioral problems of children and adolescents between 4 and 15 years of age. It can be answered by parents/guardians, teachers or the adolescents themselves. In the present study a version of the questionnaire answered by parents was used. The questionnaire, aimed at identifying mental health problems, is composed of four subscales: emotional symptoms, conduct problems, hyperactivity/attention deficit, and peer problems. Scores are assigned to each of these scales $(0,1$ or 2 as false, true or somewhat true). Then, a total score ranging from 0 to 40 is assigned at the end. According to the score, each scale is classified as normal, borderline or abnormal [17]. The presence of mental health problems was identified when the total score was greater than 16 , which is considered abnormal [17]. The questionnaire was adapted and validated for Brazil [18].

\section{Childhood depression}

It was measured by the Children's Depression Inventory (CDI). It is a screening instrument based on self-report prepared by Kovacs in 1981 which includes 27 items with three response options to be answered from 7 years of age onwards. The child selects the answer that best describes how he/she feels. It was adapted and validated by Gouveia et al. for Brazilian school children [19]. To each item 0,1 or 2 responses are assigned, according to the order of the answers - 1st, 2nd or 3rd, respectively. Then the items are summed to obtain the total score. The score from which the child was considered to be "depressed" was less than 17 points, according to a Brazilian study [19].

\section{Bottle feeding, non-nutritive sucking habits and current bruxism}

Parents were asked whether the child used a bottle, pacifier or sucked its finger ever in life. Finger sucking and pacifier use were considered non-nutritive sucking habits. Bruxism corresponded to the habit of grinding or clenching the teeth and was considered to be present if observed during sleep or when the child was awake; current bruxism was identified when parents or guardians reported that the habit had persisted until the day the interview took place.

\section{Primary headache}

Primary headache was considered to be present when the mother reported that her child presented $\geq 2$ episodes of headache in the two preceding weeks, without any associated organic symptoms, no matter how long or intense they were or where in the head they were located. This criterion was established according to the International Classification of Headache Disorders guidelines [20].

\section{Recurrent abdominal pain}

Recurrent abdominal pain was considered to be the occurrence of pain or discomfort in the stomach in the last three months, strong enough to disrupt the child's daily activities such as playing, going to school or sleeping [21].

\section{Symptoms of asthma and bronchial hyperresponsiveness}

The presence of symptoms of current asthma was investigated by adapting the questionnaire used in the asthma module of the ISAAC study [22]. The airway responsiveness was measured by the methacholine challenge test (bronchoconstrictor stimulus). The child inhaled methacholine at increasing concentrations, which started at $0.03 \mathrm{mg} / \mathrm{ml}$ and were successively doubled up to $16 \mathrm{mg} /$ $\mathrm{ml}$. The test was terminated when there was a decrease of $20 \%$ or more in forced expiratory volume in one second (FEV1) or when the last concentration of the protocol was reached. PC20, which is the concentration of methacholine causing a $20 \%$ fall in FEV1, was calculated. If PC $20 \leq$ $2 \mathrm{mg} / \mathrm{ml}$, the test was considered positive. Responsiveness was considered borderline if PC20 >2 to $16 \mathrm{mg} / \mathrm{ml}$ and normal if PC20 $>16 \mathrm{mg} / \mathrm{ml}$. For the examination the persons responsible for the children were instructed not to give the child tea, coffee, chocolate or soft drinks within 6 hours before the exam. To avoid false-positive results, the test was rescheduled if the child had had airway infection in the previous four weeks.

Asthma was considered to be present when subjective (symptoms of current asthma, or wheezing in the last 12 months) and objective criteria (presence of bronchial hyperresponsiveness) were present simultaneously or, by other definition, when subjective symptoms were reported alone.

\section{Skin tests for allergens}

Skin tests for allergy were applied by the puncture technique by trained personnel. We used the following allergens: 3 dust mites (Dermatophagoides pteronyssimus, Dermatophagoides farinae and Blomia tropicalis), cat, dog, two types of cockroaches (Periplaneta americana and Blatella German), pollen and four fungi (Alternaria alternata, Cladosporium herbarum, Aspergillus fumigatus and Penicillium notatum). The result was considered 
positive when the wheal size was over $3 \times 3 \mathrm{~mm}$ with hyperemia.

\section{Anthropometric and blood pressure measurements}

Height and weight were measured, with the children barefoot and wearing light clothing, using standard techniques [23]. The instruments used were a precision scale calibrated periodically for measuring weight and an anthropometer for measuring standing height. For the assessment of nutritional status two references were used. The criteria proposed by the International Obesity Task Force (IOTF), based on data from six countries, including Brazil, used cutoffs of BMI for each age and sex, corresponding to cutoff points for overweight and obesity in adults [24]. For low weight the cutoff point $<17 \mathrm{~kg} / \mathrm{m}^{2}$ was considered [25]. According to the American reference, children were considered underweight if BMI for age and gender was $\leq 5$ th percentile, overweight if $\mathrm{BMI}>\mathrm{P} 85$ and $\leq \mathrm{P} 95$ and obese when $\mathrm{BMI}>$ 95th percentile [26].

Blood pressure was measured three times with a digital sphygmomanometer, with cuffs adjusted for arm circumference. The measurements were performed by the same person, at 15-minute intervals with the participant resting in the sitting position, with his left arm at heart level. We calculated the average of the last two measurements. Hypertension was defined as systolic blood pressure and/or diastolic blood pressure equal to or greater than the 95th percentile for age, sex and height [27].

\section{Daily time spent in some sedentary activities}

To assess the time spent in sedentary activities, the children reported the average daily time spent watching television, playing videogames or using the computer. Average daily time spent in some sedentary activities was divided into the following categories: 0 hours, up to 4 hours, more than 4 to 8 hours and over 8 hours.

\section{Other variables}

The other variables considered were gender (male and female), child's skin color as reported by the mother/guardian (white, black, brown/mulatto and yellow/indigenous), monthly family income $(<1,1$ to $<4,4<10$ and 10 or more minimum wages), occupation of household head (non-manual, skilled manual and semi-skilled, unskilled/ unemployed), maternal schooling in years (0-4, 5-8 and 9 or more years), maternal and paternal schooling in years (0-4, 5-8 and 9 or more years),performance of domestic chores by the child, and child labor (if the child perfomed some paid work outside the home, yes/no). For some variables, missing values were also presented.

\section{Statistical analysis and correction of estimates due to the} complex sampling design

Due to the complex sampling design, children with birth weights $<1500 \mathrm{~g}, 1500 \mathrm{~g}$ to $2499 \mathrm{~g}$ and $\geq 4250 \mathrm{~g}$ were overrepresented in the sample. Therefore, the prevalence estimates and their standard errors were weighted using the svy set of commands in Stata. The weighting took into account the different probabilities of selection of each of the five groups of birth weight and preterm birth. Stratification of the sample by birth weight was also taken into account. We used the chi-square test for comparison of proportions between the two cohorts and to assess differences in the percentage of follow-up according to maternal age, schooling and marital status, parity, and child's sex.

\section{Ethical Aspects}

The reasons for the study and its methodological procedures were explained to the parents or guardians. After accepting the participation of their children in the research, they signed the consent form according to the guidelines and standards regulating research involving human subjects of the National Health Council, resolution 196/1996. Study participants were guaranteed the right to interrupt the study at any time, access to the results, confidentiality of the results, guidance and referral to specialized evaluation when necessary. The project was approved by the Research Ethics Committee of the University Hospital, Federal University of Maranhão (protocol number 3104-476/2005) and the Research Ethics Committee of the University Hospital, Faculty of Medicine of Ribeirão Preto, University of São Paulo (protocol number 6828/2004).

\section{Results}

In RP, a lower percentage of children who participated in the follow-up study were born to cohabiting mothers, to mothers aged $<20$ years, with $\leq 4$ years in comparison to eligible children who did not participate, but there was no difference regarding maternal parity and offspring sex. In $\mathrm{SL}$, a lower proportion of children were born to mothers with $\geq 12$ years of full time education, who were primiparous or gave birth to males in those who participated in the study in comparison to the eligible group who did not participate. However, there was no difference in the participants compared to non-participants regarding maternal age and marital status (Table 1). Differences in birth weight and preterm birth were observed due to the complex sampling design of the study and were corrected by weighting.

In RP there was a predominance of white children, while children of mixed ethnicity prevailed in SL. RP showed higher proportions of children from families 
with higher family incomes and whose heads were engaged in non-manual occupations. More of the children from SL (95.7\%) performed household chores than the children from RP (87.3\%). A higher proportion of children whose mothers or fathers had formal education $\geq 9$ years were seen in SL. Child labor was infrequent and did not vary between cities (Table 2).

The lifetime use of a bottle or pacifier was more frequent in RP than in SL. The number of children having the habit of finger sucking and clenching or grinding their teeth did not differ between the two cities. Mothers of children in RP reported more primary headache $(27.9 \%)$ than in SL (13.0\%). The prevalence of recurrent abdominal pain was similar in both cities, around $22 \%$ (Table 3).
Below average or poor cognitive function, whether assessed by the Raven test or the HFD test, was more prevalent in SL than in RP. Indicators of mental health problems according to the SDQ were also more prevalent in SL (47.4\%) than in RP (38.4\%). The prevalence of childhood depression was about three and a half times higher in SL (21.6\%) than in RP (6\%) (Table 4).

The prevalence of bronchial hyperresponsiveness as well as asthma was similar in both cities, both when considering only current symptoms or symptoms associated with bronchial hyperresponsiveness. RP had a higher percentage of children with positive skin tests to allergens (44.3\%) than SL (25.3\%) (Table 5).

The prevalence of overweight and obesity was higher than the prevalence of underweight among RP than SL

Table 1 Comparison of the characteristics of the participants at birth and school age

\begin{tabular}{|c|c|c|c|c|c|c|c|c|c|c|}
\hline \multirow[t]{2}{*}{ Variables } & \multicolumn{2}{|r|}{ Ribeirão } & \multicolumn{2}{|l|}{ Preto } & \multirow[b]{2}{*}{$p^{*}$} & \multirow[b]{2}{*}{$\begin{array}{c}\mathrm{n} \\
\text { Initial sample } \\
\text { (excluding } 65 \\
\text { deaths) }\end{array}$} & \multirow{2}{*}{$\begin{array}{c}\text { São } \\
n \\
\text { Eligible to } \\
\text { follow-up }\end{array}$} & \multirow{2}{*}{$\begin{array}{c}\text { Luís } \\
n \\
\text { followed } \\
\text { up }\end{array}$} & \multirow[b]{2}{*}{$\begin{array}{c}\% \\
\text { followed } \\
\text { up }\end{array}$} & \multirow[b]{2}{*}{$p^{*}$} \\
\hline & $\begin{array}{c}\text { n } \\
\text { Initial sample } \\
\text { (excluding } 48 \\
\text { deaths) }\end{array}$ & $\begin{array}{c}n \\
\text { Eligible to } \\
\text { follow-up }\end{array}$ & $\begin{array}{c}n \\
\text { followed } \\
\text { up }\end{array}$ & $\begin{array}{c}\% \\
\text { followed } \\
\text { up }\end{array}$ & & & & & & \\
\hline $\begin{array}{l}\text { Maternal age } \\
\text { (years) }\end{array}$ & & & & & 0.005 & & & & & 0.350 \\
\hline 20 to 34 & 2051 & 832 & 563 & 67.7 & & 1,577 & 610 & 442 & 72.5 & \\
\hline$\geq 35$ & 265 & 114 & 94 & 82.5 & & 101 & 41 & 32 & 78.0 & \\
\hline$<20$ & 487 & 202 & 131 & 64.9 & & 698 & 274 & 199 & 72.6 & \\
\hline Missing & 7 & 2 & 2 & 85.7 & & 2 & 1 & 0 & 0.0 & \\
\hline Marital status & & & & & $\begin{array}{c}< \\
0.001\end{array}$ & & & & & 0.670 \\
\hline Married & 1,664 & 666 & 489 & 73.5 & & 695 & 266 & 199 & 74.8 & \\
\hline Cohabiting & 690 & 291 & 158 & 54.2 & & 1,107 & 437 & 314 & 71.9 & \\
\hline Single & 338 & 147 & 106 & 72.1 & & 575 & 223 & 160 & 71.7 & \\
\hline Missing & 118 & 46 & 37 & 80.4 & & 1 & 0 & 0 & 0.0 & \\
\hline $\begin{array}{l}\text { Maternal } \\
\text { schooling } \\
\text { (years) }\end{array}$ & & & & & $\begin{array}{c}< \\
0.001\end{array}$ & & & & & $<0.001$ \\
\hline$\geq 12$ & 367 & 145 & 93 & 64.3 & & 119 & 46 & 14 & 30.4 & \\
\hline 9 to 11 & 607 & 246 & 170 & 69.2 & & 841 & 324 & 255 & 78.7 & \\
\hline 5 to 8 & 1,028 & 416 & 304 & 73.1 & & 1007 & 397 & 301 & 75.8 & \\
\hline$\leq 4$ & 618 & 267 & 158 & 59.1 & & 405 & 157 & 103 & 65.6 & \\
\hline Missing & 190 & 76 & 65 & 85.2 & & 6 & 2 & 0 & 0.0 & \\
\hline Parity & & & & & 0.361 & & & & & 0.049 \\
\hline 1 & 1148 & 467 & 313 & 67.0 & & 1156 & 457 & 316 & 69.1 & \\
\hline 2 to 4 & 1474 & 600 & 423 & 70.5 & & 1119 & 424 & 321 & 75.7 & \\
\hline$\geq 5$ & 160 & 73 & 46 & 63.0 & & 103 & 45 & 36 & 80.0 & \\
\hline Missing & 28 & 10 & 8 & 80.0 & & 0 & 0 & 0 & 0.0 & \\
\hline Sex & & & & & 0.714 & & & & & 0.001 \\
\hline Male & 1425 & 581 & 402 & 69.2 & & 1295 & 509 & 348 & 68.4 & \\
\hline Female & 1384 & 569 & 388 & 68.2 & & 1083 & 417 & 325 & 77.9 & \\
\hline Missing & 1 & 0 & 0 & 0.0 & & 0 & 0 & 0 & 0.0 & \\
\hline Total & 2810 & 1150 & 790 & 68.7 & & 2378 & 926 & 673 & 72.7 & \\
\hline
\end{tabular}

Ribeirão Preto, 1994 and 2004/05 and São Luís, 1997/98 and 2005/06

* $\mathrm{P}$ value calculated by the chi-squared test. 
Table 2 Socio-demographic factors, skin color of the child, performance of domestic chores by the child and child labor in the two birth cohorts

\begin{tabular}{|c|c|c|c|c|c|}
\hline \multirow[t]{2}{*}{ Variables } & \multicolumn{3}{|c|}{ Ribeirão Preto } & \multirow{2}{*}{$\begin{array}{c}\text { São Luís } \\
\% \text { weighted* }\end{array}$} & \multirow[t]{2}{*}{$P$ value } \\
\hline & $\mathrm{n}$ & $\%$ weighted* & $\mathrm{n}$ & & \\
\hline Sex & & & & & 0.724 \\
\hline Female & 402 & 50.8 & 348 & 51.7 & \\
\hline Male & 388 & 49.2 & 325 & 48.3 & \\
\hline Skin color of the child & & & & & $<0.001$ \\
\hline White & 444 & 56.3 & 158 & 23.5 & \\
\hline Black & 31 & 4.3 & 50 & 7.1 & \\
\hline Brown/Mulatto & 304 & 37.9 & 463 & 69.1 & \\
\hline Yellow/Indigenous & 11 & 1.5 & 2 & 0.3 & \\
\hline Monthly family income (minimum wages) & & & & & $<0.001$ \\
\hline$<1$ & 36 & 4.5 & 149 & 23.0 & \\
\hline 1 to $<4$ & 396 & 50.1 & 454 & 69.8 & \\
\hline 4 to $<10$ & 243 & 32.6 & 33 & 4.8 & \\
\hline$\geq 10$ & 103 & 12.8 & 19 & 2.5 & \\
\hline Missing & 12 & - & 18 & - & \\
\hline Occupation of household head & & & & & $<0.001$ \\
\hline Non-manual & 150 & 19.1 & 85 & 12.3 & \\
\hline Manual skilled/semiskilled & 296 & 37.5 & 200 & 30.0 & \\
\hline Unskilled manual/unemployed & 340 & 43.4 & 384 & 57.8 & \\
\hline Missing & 4 & - & 4 & - & \\
\hline Maternal schooling (years) & & & & & 0.001 \\
\hline 0 to 4 & 345 & 43.9 & 223 & 34.4 & \\
\hline 5 to 8 & 164 & 21.6 & 154 & 23.4 & \\
\hline$\geq 9$ & 273 & 34.5 & 278 & 42.2 & \\
\hline Missing & 8 & - & 18 & - & \\
\hline Paternal schooling (years) & & & & & 0.002 \\
\hline 0 to 4 & 372 & 48.0 & 248 & 38.9 & \\
\hline 5 to 8 & 148 & 19.5 & 128 & 20.3 & \\
\hline$\geq 9$ & 261 & 32.5 & 256 & 40.8 & \\
\hline Missing & 9 & - & 41 & - & \\
\hline Performance of domestic chores by the child & & & & & $<0.001$ \\
\hline Yes & 686 & 87.3 & 644 & 95.7 & \\
\hline No & 104 & 12.7 & 27 & 4.4 & \\
\hline Missing & 0 & - & 2 & - & \\
\hline Child labor & & & & & 0.269 \\
\hline Yes & 24 & 2.9 & 13 & 1.9 & \\
\hline No & 766 & 97.2 & 659 & 98.1 & \\
\hline Missing & 0 & - & 1 & - & \\
\hline
\end{tabular}

Ribeirão Preto, 2004/05 and São Luís, 2005/06.

* Percentages may not add to $100 \%$ because of rounding. Missing values were excluded from percentages and P-value calculations.

children according to two criteria (Table 6). SL children spent more hours per day in sedentary activities (TV, videogames or computer) with an average of 5.6 hours per day, while in RP the average time spent in these activities was 4.6 hours per day $(\mathrm{p}<0.001)$. The prevalence of hypertension in Ribeirão Preto (10.9\%) was more than twice that observed in São Luís (4.6\%). High systolic blood pressure was more than three times higher in Ribeirão Preto (9.3\%) than in SL (2.5\%). There were no differences in the prevalence of high diastolic blood pressure between the two cities (Table 6).

\section{Discussion}

These two Brazilian cities are at different stages of the epidemiological transition. In the more developed city there was greater lifetime use of a bottle or pacifier, a greater prevalence of primary headache and atopy and a higher prevalence of overweight, obesity and 
Table 3 Lifetime bottle and pacifier use, non-nutritive sucking habits, current bruxism, primary headache and recurrent abdominal pain in the two birth cohorts

\begin{tabular}{|c|c|c|c|c|c|}
\hline \multirow[t]{2}{*}{ Variables } & \multicolumn{2}{|c|}{ Ribeirão Preto } & \multicolumn{2}{|r|}{ São Luís } & \multirow{2}{*}{$\begin{array}{c}P \\
\text { value }\end{array}$} \\
\hline & $\mathrm{n}$ & $\begin{array}{c}\% \\
\text { weighted }\end{array}$ & $n$ & $\begin{array}{c}\% \\
\text { weighted* }\end{array}$ & \\
\hline Lifetime bottle use & & & & & $<0.001$ \\
\hline Yes & 709 & 89.6 & 463 & 68.3 & \\
\hline No & 79 & 10.4 & 206 & 30.7 & \\
\hline Missing & 2 & - & 4 & - & \\
\hline Lifetime pacifier use & & & & & $<0.001$ \\
\hline Yes & 502 & 63.8 & 263 & 38.7 & \\
\hline No & 286 & 36.2 & 405 & 61.3 & \\
\hline Missing & 2 & - & 5 & - & \\
\hline Lifetime finger sucking & & & & & 0.137 \\
\hline Yes & 80 & 9.9 & 80 & 12.4 & \\
\hline No & 708 & 90.1 & 591 & 87.6 & \\
\hline Missing & 2 & - & 2 & - & \\
\hline Non-nutritive sucking habits (lifetime pacifier use or finger sucking) & & & & & $<0.001$ \\
\hline Yes & 543 & 69.1 & 322 & 47.9 & \\
\hline No & 243 & 30.9 & 346 & 52.1 & \\
\hline Missing & 4 & - & 5 & - & \\
\hline Current bruxism (teeth clenching or grinding) & & & & & 0.903 \\
\hline Yes & 228 & 28.9 & 192 & 29.2 & \\
\hline No & 551 & 71.1 & 472 & 70.8 & \\
\hline Missing & 11 & - & 9 & - & \\
\hline Primary headache ( 2 or more episodes in the two preceding weeks) & & & & & $<0.001$ \\
\hline Yes & 206 & 27.9 & 87 & 13.0 & \\
\hline No & 556 & 72.1 & 568 & 87.0 & \\
\hline Missing & 28 & - & 18 & - & \\
\hline $\begin{array}{l}\text { Recurrent abdominal pain (pain in the last three months that affected the child's daily } \\
\text { activities) }\end{array}$ & & & & & 0.887 \\
\hline Yes & 172 & 21.9 & 144 & 21.6 & \\
\hline No & 617 & 78.1 & 529 & 78.4 & \\
\hline
\end{tabular}

Ribeirão Preto, 2004/05 and São Luís, 2005/06.

* Percentages may not add to $100 \%$ because of rounding. Missing values were excluded from percentages and P-value calculations.

hypertension. In the less developed city there was a higher percentage of children performing household chores, having lower than average cognitive function, mental health problems, depression and underweight. There was no difference between cities in the prevalence of bruxism, recurrent abdominal pain, asthma or bronchial hyperresponsiveness.

The prevalence of non-nutritive sucking habits was almost one and half times higher in RP than in SL. These prevalence rates are higher compared to studies conducted in rural (3\%) [28] and urban areas (25.5\%) [29] of India. The prevalence observed in SL was similar to that observed in Saudi Arabia (48.4\%) [30] and in a Brazilian study (43.5\%) [31]. The high prevalence of nonnutritive sucking habits observed suggests that the development of malocclusions will be frequent in these populations [32].
The current prevalence of bruxism was high in both cities, with no statistically significant difference between them. These prevalences were lower than those seen in Boston, 38\% [33] and Canada, 45.6\% [34].

The prevalence of primary headache, considered as the occurrence of two or more episodes in the last 15 days, in RP was more than twice that seen in SL. These high prevalence rates indicate that headache is an important public health problem among children. Frequent and severe headaches in the past year was reported by $17.1 \%$ of children and adolescents aged 4 to 18 years in the U. S. [35]. In Istanbul, $46.2 \%$ of the children reported headaches in the past year [36].

Prevalences of recurrent abdominal pain were high and did not differ between cities. Prevalence rates were higher than those reported in an international review, which ranged from $0.3 \%$ to $19 \%$ [21], indicating the 
Table 4 Cognitive function, mental health problems and childhood depression in the two birth cohorts

\begin{tabular}{|c|c|c|c|c|c|}
\hline \multirow[t]{2}{*}{ Variables } & \multicolumn{3}{|c|}{ Ribeirão Preto } & \multirow{2}{*}{$\begin{array}{c}\text { São Luís } \\
\% \text { weighted* }\end{array}$} & \multirow[t]{2}{*}{$P$ value } \\
\hline & $\mathrm{n}$ & \% weighted* & $\mathrm{n}$ & & \\
\hline Raven's test & & & & & $<0.001$ \\
\hline Below average or poor & 103 & 12.2 & 202 & 28.9 & \\
\hline Average or above average & 672 & 87.8 & 468 & 71.1 & \\
\hline Missing & 15 & - & 3 & - & \\
\hline Human Figure Drawing (HFD) & & & & & $<0.001$ \\
\hline Below average, borderline or poor & 171 & 21.5 & 231 & 34.2 & \\
\hline Average or above average & 603 & 78.5 & 435 & 65.8 & \\
\hline Missing & 16 & - & 7 & - & \\
\hline Strengths and Difficulties Questionnaire & & & & & $<0.001$ \\
\hline Abnormal & 307 & 38.4 & 318 & 47.4 & \\
\hline Borderline & 126 & 16.3 & 116 & 17.4 & \\
\hline Normal & 351 & 45.2 & 236 & 35.2 & \\
\hline Missing & 6 & - & 3 & - & \\
\hline Children's Depression Inventory (CDI) & & & & & $<0.001$ \\
\hline Positive & 56 & 6.0 & 141 & 21.6 & \\
\hline Negative & 718 & 94.0 & 529 & 78.4 & \\
\hline Missing & 16 & - & 3 & - & \\
\hline
\end{tabular}

Ribeirão Preto, 2004/05 and São Luís, 2005/06.

* Percentages may not add to $100 \%$ because of rounding. Missing values were excluded from percentages and P-value calculations.

need for further research on this neglected public health problem.

The higher prevalence of below average cognitive function in the less developed city by both the Raven test and the human figure drawing, probably reflects socioeconomic differences between the two cities, and differences in stardardization, since the benchmark for both tests was established with children from the Southeast. The high prevalence of mental health problems in this study, as measured by the SDQ was surprising. These prevalences were higher than those detected in studies in Germany (14.5\%) [12] and Egypt (20.6\%) [37]. Brazilian studies have found prevalence rates of $20.6 \%$ [38] and $24.6 \%$ [39], also lower than those detected in

Table 5 Asthma, bronchial hyperresponsiveness and atopy in the two birth cohorts

\begin{tabular}{|c|c|c|c|c|c|}
\hline \multirow[t]{2}{*}{ Variables } & \multicolumn{3}{|c|}{ Ribeirão Preto } & \multirow{2}{*}{$\begin{array}{c}\text { São Luís } \\
\text { \% weighted* }\end{array}$} & \multirow[t]{2}{*}{$P$ value } \\
\hline & $\mathrm{n}$ & $\%$ weighted* & $\mathrm{n}$ & & \\
\hline Wheezing in the last 12 months & & & & & 0.957 \\
\hline Yes & 60 & 18.0 & 58 & 17.8 & \\
\hline No & 268 & 82.0 & 270 & 82.2 & \\
\hline Missing & - & - & 2 & - & \\
\hline Bronchial hyperresponsiveness ** & & & & & 0.069 \\
\hline Yes & 135 & 39.6 & 111 & 32.5 & \\
\hline No & 193 & 60.4 & 219 & 67.5 & \\
\hline Asthma *** & & & & & 0.209 \\
\hline Yes & 34 & 10.2 & 25 & 7.3 & \\
\hline No & 294 & 89.8 & 305 & 92.7 & \\
\hline Atopy $* * *$ & & & & & $<0.001$ \\
\hline Positive & 142 & 44.3 & 81 & 25.3 & \\
\hline Negative & 185 & 55.7 & 242 & 74.7 & \\
\hline Missing & 1 & - & 7 & - & \\
\hline
\end{tabular}

Ribeirão Preto, 2004/05 and São Luís, 2005/06.

* Percentages may not add to $100 \%$ because of rounding. Missing values were excluded from percentages and P-value calculations.

** PC20 $\leq 2 \mathrm{mg} / \mathrm{ml}$

*** Asthma defined by a subjective criterion (wheezing in the last 12 months) plus an objective criterion (bronchial hyperresponsiveness)

**** Atopy was defined as at least one positive skin test for some allergens 
Table 6 Nutritional status, time spent in sedentary activities and arterial hypertension in the two birth cohorts

\begin{tabular}{|c|c|c|c|c|c|}
\hline \multirow[t]{2}{*}{ Variables } & \multicolumn{3}{|c|}{ Ribeirão Preto } & \multirow{2}{*}{$\begin{array}{c}\text { São Luís } \\
\% \text { weighted* }\end{array}$} & \multirow[t]{2}{*}{$P$ value } \\
\hline & $\mathrm{n}$ & $\%$ weighted* & $\mathbf{n}$ & & \\
\hline Nutritional status according to Cole et al. & & & & & $<0.001$ \\
\hline Underweight & 32 & 3.6 & 39 & 5.8 & \\
\hline Normal & 542 & 68.6 & 595 & 88.8 & \\
\hline Overweight & 139 & 18.2 & 25 & 3.6 & \\
\hline Obesity & 75 & 9.5 & 13 & 1.8 & \\
\hline Unknown & 2 & - & 1 & - & \\
\hline Nutritional status according to Must et al. & & & & & $<0.001$ \\
\hline Underweight & 98 & 11.2 & 112 & 16.1 & \\
\hline Normal & 492 & 63.4 & 522 & 78.5 & \\
\hline Overweight & 104 & 13.5 & 24 & 3.5 & \\
\hline Obesity & 94 & 11.9 & 14 & 1.9 & \\
\hline Unknown & 2 & - & 1 & - & \\
\hline Time spent in sedentary activities (hours per day) ** & & & & & $<0.001$ \\
\hline 0 & 13 & 2.0 & 6 & 1.0 & \\
\hline 1 to 4 & 249 & 39.2 & 173 & 27.3 & \\
\hline$>4$ to 8 & 371 & 57.0 & 399 & 60.1 & \\
\hline$>8$ & 15 & 1.9 & 73 & 11.6 & \\
\hline Missing & 142 & - & 22 & - & \\
\hline Systolic blood pressure $* * *$ & & & & & $<0.001$ \\
\hline Normal & 687 & 90.7 & 647 & 97.5 & \\
\hline High & 69 & 9.3 & 18 & 2.5 & \\
\hline Missing & 34 & - & 8 & & \\
\hline Diastolic blood pressure ${ }^{* * *}$ & & & & & 0.673 \\
\hline Normal & 742 & 95.9 & 630 & 95.4 & \\
\hline High & 29 & 4.1 & 30 & 4.6 & \\
\hline Missing & 19 & - & 13 & & \\
\hline Arterial hypertension $* * * *$ & & & & & $<0.001$ \\
\hline No & 665 & 89.0 & 626 & 95.4 & \\
\hline Yes & 79 & 10.9 & 31 & 4.6 & \\
\hline Missing & 46 & - & 16 & - & \\
\hline
\end{tabular}

Ribeirão Preto, 2004/05 and São Luís, 2005/06.

* Percentages may not add to $100 \%$ because of rounding. Missing values were excluded from percentages and P-value calculations.

** Daily time spent watching TV, playing videogames or on the computer

*** $\geq$ P95 for age, sex and height

**** Systolic and/or diastolic blood pressure $\geq P 95$ for age, sex and height

the present study. Methodological differences in these studies could not possibly justify such different rates. It is noteworthy that the SDQ tracks behavioral problems bud does not confirm the diagnosis.

The prevalence of childhood depression, as measured by the CDI was three and a half times greater in SL than in RP. The prevalence was high in SL, more than four times the prevalence of depression in children and adolescents aged 9-17 years, which has been estimated at 5\% [40]. Using the CDI, a study conducted in Northern Ireland showed a prevalence of $11.6 \%$ in children aged 11 to 15 years [41]. In Brazil, the prevalence was 1.5\% among children aged 7 to 14 years from a private school in Ribeirão Preto [42] and 13.9\% among schoolchildren aged 7 to 13 years from a public school of Minas Gerais [40].
No statistically significant differences were observed between the two cities in asthma prevalence, which was around $18.0 \%$ when we considered the presence of wheezing in the past 12 months These figures are similar to those reported in the ISAAC study, in English speaking countries and in Latin America, in which the highest prevalence reported was $32.2 \%$, also using as a criterion for the diagnosis of asthma wheezing within the past 12 months [43]. When we added an objective measure (the methacholine challenge test) these prevalence rates fell to about half (10.2\% in RP and $7.3 \%$ in SL), suggesting that only using symptoms to diagnose asthma in epidemiological studies produces an overestimate of prevalence, due to the possible inclusion of false-positive results. The prevalence of bronchial hyperresponsiveness was high, 
considering a cutoff point of 2 , and similar when comparing RP (39.6\%) to SL (32.5\%). Among children aged 7 to 10 years, the prevalence was $21.6 \%$ in the UK [44] and $28 \%$ in Boston [45], but those studies considered a cutoff point of 4.

Ribeirão Preto (44.3\%) had a higher percentage of atopic children than São Luís (25.3\%). In a study conducted in Porto Alegre on students aged 10 to 18 years, which used as a criterion for atopy at least one positive skin test, the prevalence was 50\% [46], slightly higher than the values of RP and much more higher than the values of SL. In another study in China, also using a similar criterion for detecting atopy, prevalences ranged from $23.9 \%$ in Beijing to $41.2 \%$ in Hong Kong among schoolchildren aged 9 to 11 years, [47].

This difference in the prevalence of atopy between the two Brazilian cities may somehow be related to differences in lifestyle between developed and developing sites. It is thought that this phenomenon could also be related to differences in breastfeeding, smoking and infections. According to the hygiene hypothesis, in places with low transmission rates of pathogens, the immune system tends to shift to atopic responses [46]. However, based on this assumption, it would be expected that the prevalence rates of asthma and bronchial hyperresponsiveness would have been higher in the more developed city of $\mathrm{RP}$, which was not the case.

The prevalence of obesity was higher in RP than in SL by two criteria. According to the IOTF, the prevalence of obesity in RP was $9.5 \%$, lower than that observed in the United States in 2003-04 among children aged 6 to 11 years $(18.8 \%)$ [48], but higher than the percentages observed in England in 2006/07 among children aged 810 years (5.6\% to $6.3 \%$ for boys and girls) [49] and Rio de Janeiro in 1999 (5.0\% for boys aged 7-14 years) [50]. The prevalence of obesity in SL (1.8\%) was much lower than those observed in all the studies reported above. The prevalence of overweight in RP (18.2\%) showed values similar to those of the United States (18.4\%) [48], and England (19.8\% to $23.9 \%$ for boys and girls) [49]. These results are consistent with studies showing the occurrence of the nutrition transition in developing countries. $\mathrm{RP}$ is experiencing an advanced stage of the nutrition transition, in which prevalence rates of overweight and obesity are higher than child malnutrition, while in SL child malnutrition rates $(5.8 \%)$ are still higher than overweight $(3.6 \%)$ and obesity rates $(1.8 \%)$.

The average time spent in sedentary activities was greater in SL (5.6 hours per day) than in RP (4.6 hours per day). These results are consistent with national studies that show 3 to $5 \mathrm{~h} /$ day, on average, spent in sedentary activities [51,52], but a little above average hours found in international studies, which ranged from 2.2 to $4.5 \mathrm{~h} /$ day $[53,54]$. The children from SL spent more time watching TV and less time on videogames and computers, in contrast to from RP, where they spend less time watching TV and more time on electronic games (data not shown). This difference may be associated with the socioeconomic profile of the two cities, where availability of technology such as computers and videogames is greater for children in the more developed city.

The prevalence of arterial hypertension in RP was more than twice that observed in SL. International data show that the prevalence of hypertension ranged from $2.2 \%$ to $4.5 \%[55,56]$, The prevalence of hypertension in SL was similar to those observed in those studies, while in RP the prevalence was higher. In studies conducted in Brazil, the prevalence of hypertension ranged from $2.5 \%$ to $9.4 \%[57,58]$.

This study is one of the few population cohort studies conducted in developing countries that investigated non-communicable diseases among schoolchildren, contrasting a more developed with a less developed city. The strategy of oversampling LBW babies was used to increase the study power. Follow-up rates were satisfactory $(68.7 \%$ in $\mathrm{RP}$ and $72.7 \%$ in $\mathrm{SL})$.

In $\mathrm{SL}$, children born to primiparous mothers with $\geq 12$ years of schooling, or males had lower follow-up rates than their counterparts. In RP, participation rates were lower for children whose mothers lived in consensual union, had $\leq 4$ years of full time education or were age $<$ 20 years. It is possible that these differences might have led to an overestimation of some prevalence estimates in $\mathrm{SL}$ and to an underestimation in RP (eg, mental health problems), because groups of higher education were underrepresented in the former and overrepresented in the latter. The small age difference of two years was a limitation in comparing prevalence rates between the two cities. Another limitation is that prevalence estimates of asthma, bronchial hyperresponsiveness and atopy were obtained in a subsample drawn by convenience.

Differences in prevalence from other studies regarding the various indicators may have been due to real population differences in prevalence, differences in the age groups studied or differences regarding the methods of measurement, such as when assessing the prevalence of hypertension. In some studies used for comparison only one blood pressure measurement was taken, while in others two or three measurements were taken on one or more occasions.

\section{Conclusions}

Some non-communicable diseases were highly prevalent among these Brazilian children, especially in the more developed city. Some high rates suggest that the burden of non-communicable diseases will be high in the future, especially mental health problems. 


\section{Acknowledgements}

This research was supported by CNPq (Conselho Nacional de Desenvolvimento Científico e Tecnológico - Brazilian National Research Council), grants 523474/96-2 and 520664/98-1, and FAPESP (Fundação de Amparo à Pesquisa do Estado de São Paulo - São Paulo Research Foundation), grants 93/0525-0, 97/09517-1 and 00/0908-7. We thank the school directors who kindly agreed to grant access to the children and their families. We also thank all children and their relatives who provided valuable information to foster public health.

\section{Author details}

'Departamento de Saúde Pública, Universidade Federal do Maranhão, São Luís, MA, Brasil. ${ }^{2}$ Departamento de Puericultura e Pediatria, Faculdade de Medicina de Ribeirão Preto, Universidade de São Paulo, Ribeirão Preto, SP, Brasil. ${ }^{3}$ Departamento de Medicina I, Universidade Federal do Maranhão, São Luís, MA, Brasil. ${ }^{4}$ Departamento de Clínica Médica, Faculdade de Medicina de Ribeirão Preto, Universidade de São Paulo, Ribeirão Preto, SP, Brasil. ${ }^{5}$ Departamento de Neurociências e Ciências do Comportamento, Faculdade de Medicina de Ribeirão Preto, Universidade de São Paulo, Ribeirão Preto, SP, Brasil. ${ }^{6}$ Departamento de Medicina III, Universidade Federal do Maranhão, São Luís, MA, Brasil.

\section{Authors' contributions}

AAS, MAB and HB conceived the study. AAS, TSP, MLF, NAS and MRG performed the statistical analysis. VCC, RFB, EOV, MRG, AAS, TSP, MLF, NAS, MRG, JDR, SRL and VSR analyzed the data. AAS, TSP, MLF, NAS, JDR, MAB, HB and wrote the paper. All authors read and approved the final version of the manuscript.

\section{Competing interests}

The authors declare that they have no competing interests.

Received: 26 January 2011 Accepted: 21 June 2011

Published: 21 June 2011

\section{References}

1. Doll R: Cohort studies: history of the method. I. Prospective cohort studies. Soz Praventivmed 2001, 46:75-86.

2. Gluckman PD, Hanson MA, Mitchell MD: Developmental origins of health and disease: reducing the burden of chronic disease in the next generation. Genome Med 2:14.

3. Barker DJ: The developmental origins of adult disease. J Am Coll Nutr 2004, 23:588S-595S.

4. Perel P, Casas JP, Ortiz Z, Miranda JJ: Noncommunicable diseases and injuries in Latin America and the Caribbean: time for action. PLoS Med 2006, 3:e344.

5. Piegas LS, Avezum A, Pereira JC, Neto JM, Hoepfner C, Farran JA, Ramos RF, Timerman A, Esteves JP: Risk factors for myocardial infarction in Brazil. Am Heart J 2003, 146:331-338.

6. Cardoso VC, Simoes VM, Barbieri MA, Silva AA, Bettiol H, Alves MT, Goldani MZ: Profile of three Brazilian birth cohort studies in Ribeirao Preto, SP and Sao Luis, MA. Braz J Med Biol Res 2007, 40:1165-1176.

7. Barbieri MA, Bettiol H, Silva AA, Cardoso VC, Simoes VM, Gutierrez MR, Castro JA, Vianna ES, Foss MC, Dos Santos JE, Queiroz RG: Health in early adulthood: the contribution of the 1978/79 Ribeirao Preto birth cohort. Braz J Med Biol Res 2006, 39:1041-1055.

8. Barros FC, Victora CG, Barros AJ, Santos IS, Albernaz E, Matijasevich A, Domingues MR, Sclowitz IK, Hallal PC, Silveira MF, Vaughan JP: The challenge of reducing neonatal mortality in middle-income countries: findings from three Brazilian birth cohorts in 1982, 1993, and 2004. Lancet 2005, 365:847-854.

9. Bettiol H, Barbieri MA, Gomes UA, Andrea M, Goldani MZ, Ribeiro ER: Perinatal health: methodology and characteristics of the studied population. Rev Saude Publica 1998, 32:18-28.

10. Silva AA, Coimbra LC, da Silva RA, Alves MT, Lamy Filho F, Carvalho Lamy Z, Gomide Mochel E, Aragao VM, Ribeiro VS, Tonial SR, Barbieri MA: Perinatal health and mother-child health care in the municipality of Sao Luis, Maranhao State, Brazil. Cad Saude Publica 2001, 17:1413-1423.

11. Wang Y, Monteiro C, Popkin BM: Trends of obesity and underweight in older children and adolescents in the United States, Brazil, China, and Russia. Am J Clin Nutr 2002, 75:971-977.
12. Ravens-Sieberer $U$, Wille $N$, Erhart M, Bettge $S$, Wittchen HU, Rothenberger A, Herpertz-Dahlmann B, Resch F, Holling H, Bullinger M, et al: Prevalence of mental health problems among children and adolescents in Germany: results of the BELLA study within the National Health Interview and Examination Survey. Eur Child Adolesc Psychiatry 2008, 17(Suppl 1):22-33.

13. Batty GD: Examining life-course influences on chronic disease: the Ribeirao Preto and Sao Luis birth cohort studies (Brazil). Braz J Med Biol Res 2007, 40:1159-1162.

14. Asher MI, Keil U, Anderson HR, Beasley R, Crane J, Martinez F, Mitchell EA, Pearce N, Sibbald B, Stewart AW, et al: International Study of Asthma and Allergies in Childhood (ISAAC): rationale and methods. Eur Respir J 1995, 8:483-491.

15. Angelini AL, Alves ICB, Custódio EM, Duarte WF: Manual Matrizes Progressivas Coloridas de Raven (Escala Especial): Padronização Brasileira São Paulo: Casa do Psicólogo; 1987

16. Wechsler SM: DFH III: O Desenho da Figura Humana - Avaliação do Desenvolvimento Cognitivo de Crianças Brasileiras. 3 edition. Campinas: Editora da Pontifícia Universidade Católica de São Paulo; 2003.

17. Goodman R: The Strengths and Difficulties Questionnaire: a research note. J Child Psychol Psychiatry 1997, 38:581-586.

18. Fleitlich B, Goodman R: Social factors associated with child mental health problems in Brazil: cross sectional survey. BMJ 2001, 323:599-600.

19. Gouveia W, Barbosa GA, Almeida HJF, Gaião AA: Children's depression inventory - CDI: adaptation study with students of João Pessoa. J Bras Psiq 1995, 44:345-349.

20. Headache Classification Subcommittee of the International Headache Society: The International Classification of Headache Disorders: 2nd edition. Cephalalgia 2004, 24(Suppl 1):9-160.

21. Chitkara DK, Rawat DJ, Talley NJ: The epidemiology of childhood recurrent abdominal pain in Western countries: a systematic review. Am J Gastroenterol 2005, 100:1868-1875.

22. Worldwide variations in the prevalence of asthma symptoms: the International Study of Asthma and Allergies in Childhood (ISAAC). Eur Respir J 1998, 12:315-335.

23. Cameron N: The measurement of human growth London \& Sidney: Croom Helm; 1984

24. Cole TJ, Bellizzi MC, Flegal KM, Dietz WH: Establishing a standard definition for child overweight and obesity worldwide: international survey. Bmj 2000, 320:1240-1243.

25. Cole TJ, Flegal KM, Nicholls D, Jackson AA: Body mass index cut offs to define thinness in children and adolescents: international survey. $B m$ j 2007, 335:194.

26. Must A, Dallal GE, Dietz WH: Reference data for obesity: 85th and 95th percentiles of body mass index (wt/ht2) and triceps skinfold thickness. Am J Clin Nutr 1991, 53:839-846.

27. National High Blood Pressure Education Program Working Group on High Blood Pressure in Children and Adolescents: The fourth report on the diagnosis, evaluation, and treatment of high blood pressure in children and adolescents. Pediatrics 2004, 114:555-576.

28. Guaba K, Ashima G, Tewari A, Utreja A: Prevalence of malocclusion and abnormal oral habits in North Indian rural children. J Indian Soc Pedod Prev Dent 1998, 16:26-30

29. Kharbanda OP, Sidhu SS, Sundaram K, Shukla DK: Oral habits in school going children of Delhi: a prevalence study. J Indian Soc Pedod Prev Dent 2003, 21:120-124.

30. Farsi NM, Salama FS: Sucking habits in Saudi children: prevalence, contributing factors and effects on the primary dentition. Pediatr Dent 1997, 19:28-33.

31. Macena MC, Katz CR, Rosenblatt A: Prevalence of a posterior crossbite and sucking habits in Brazilian children aged 18-59 months. Eur J Orthod 2009, 31:357-361.

32. Emmerich A, Fonseca L, Elias AM, de Medeiros UV: [The relationship between oral habits, oronasopharyngeal alterations, and malocclusion in preschool children in Vitoria, Espirito Santo, Brazil]. Cad Saude Publica 2004, 20:689-697.

33. Cheifetz AT, Osganian SK, Allred EN, Needleman HL: Prevalence of bruxism and associated correlates in children as reported by parents. J Dent Child (Chic) 2005, 72:67-73.

34. Petit D, Touchette E, Tremblay RE, Boivin M, Montplaisir J: Dyssomnias and parasomnias in early childhood. Pediatrics 2007, 119:e1016-1025. 
35. Lateef TM, Merikangas KR, He J, Kalaydjian A, Khoromi S, Knight E, Nelson KB: Headache in a national sample of American children: prevalence and comorbidity. J Child Neurol 2009, 24:536-543.

36. Isik U, Topuzoglu A, Ay P, Ersu RH, Arman AR, Onsuz MF, Karavus M, Dagli $E$ : The prevalence of headache and its association with socioeconomic status among schoolchildren in istanbul, Turkey. Headache 2009, 49:697-703.

37. Elhamid AA, Howe A, Reading R: Prevalence of emotional and behavioural problems among 6-12 year old children in Egypt. Soc Psychiatry Psychiatr Epidemiol 2009, 44:8-14.

38. Cury CR, Golfeto JH: Strengths and difficulties questionnaire (SDQ): a study of school children in Ribeirao Preto. Rev Bras Psiquiatr 2003, 25:139-145.

39. Paula CS, Duarte CS, Bordin IA: Prevalence of mental health problems in children and adolescents from the outskirts of Sao Paulo City: treatment needs and service capacity evaluation. Rev Bras Psiquiatr 2007, 29:11-17.

40. Fonseca MHG, Ferreira RA, Fonseca SG: Prevaléncia de sintomas depressivos em escolares. Pediatr (São Paulo) 2005, 27:223-232.

41. Donnelly M: Depression among adolescents in Northern Ireland. Adolescence 1995, 30:339-350.

42. Baptista CA, Golfeto JH: Prevalência de depressão em escolares de 7 a 14 anos. Rev Psiq Clin 2000, 27:253-256.

43. International Study of Asthma and Allergies in Childhood (ISAAC) Steering Comittee: Worldwide variations in the prevalence of asthma symptoms: the International Study of Asthma and Allergies in Childhood (ISAAC). Eur Respir J 1998, 12:315-335.

44. Arshad SH, Kurukulaaratchy RJ, Fenn M, Matthews S: Early life risk factors for current wheeze, asthma, and bronchial hyperresponsiveness at 10 years of age. Chest 2005, 127:502-508.

45. Tepas EC, Litonjua AA, Celedon JC, Sredl D, Gold DR: Sensitization to aeroallergens and airway hyperresponsiveness at 7 years of age. Chest 2006, 129:1500-1508.

46. Fiore RW, Comparsi AB, Reck CL, Oliveira JK, Pampanelli KB, Fritscher CC: Asthma and atopy prevalence in a group of students from Porto Alegre, Rio Grande do Sul. J Pneumol 2001, 27:237-242.

47. Wong GW, Hui DS, Chan HH, Fok TF, Leung R, Zhong NS, Chen YZ, Lai CK: Prevalence of respiratory and atopic disorders in Chinese schoolchildren. Clin Exp Allergy 2001, 31:1225-1231.

48. Ogden CL, Carroll MD, Curtin LR, McDowell MA, Tabak CJ, Flegal KM: Prevalence of overweight and obesity in the United States, 1999-2004. Jama 2006, 295:1549-1555.

49. Stamatakis E, Wardle J, Cole TJ: Childhood obesity and overweight prevalence trends in England: evidence for growing socioeconomic disparities. Int J Obes (Lond) 2010, 34:41-47.

50. Anjos LA, Castro IR, Engstrom EM, Azevedo AM: Growth and nutritional status in a probabilistic sample of schoolchildren from Rio de Janeiro, 1999. Cad Saude Publica 2003, 19(Suppl 1):S171-179.

51. Ribeiro RQ, Lotufo PA, Lamounier JA, Oliveira RG, Soares JF, Botter DA: Additional cardiovascular risk factors associated with excess weight in children and adolescents: the Belo Horizonte heart study. Arq Bras Cardiol 2006, 86:408-418.

52. da Silva RC, Malina RM: Level of physical activity in adolescents from Niteroi, Rio de Janeiro, Brazil. Cad Saude Publica 2000, 16:1091-1097.

53. Lioret S, Maire B, Volatier JL, Charles MA: Child overweight in France and its relationship with physical activity, sedentary behaviour and socioeconomic status. Eur J Clin Nutr 2007, 61:509-516.

54. Robinson TN: Television viewing and childhood obesity. Pediatr Clin North Am 2001, 48:1017-1025.

55. Chiolero A, Cachat F, Burnier M, Paccaud F, Bovet P: Prevalence of hypertension in schoolchildren based on repeated measurements and association with overweight. J Hypertens 2007, 25:2209-2217.

56. Sorof JM, Lai D, Turner J, Poffenbarger T, Portman RJ: Overweight, ethnicity, and the prevalence of hypertension in school-aged children. Pediatrics 2004, 113:475-482.

57. Moura AA, Silva MA, Ferraz MR, Rivera IR: Prevalence of high blood pressure in children and adolescents from the city of Maceio, Brazil. J Pediatr (Rio J) 2004, 80:35-40.

58. Rezende DF, Scarpelli RA, de Souza GF, da Costa JO, Scarpelli AM, Scarpelli PA, de Carvalho GB, D'Agostini HM, Pedrosa JC: Prevalence of systemic hypertension in students aged 7 to 14 years in the municipality of Barbacena, in the State of Minas Gerais, in 1999. Arq Bras Cardiol 2003, 81:381-386

\section{Pre-publication history}

The pre-publication history for this paper can be accessed here: http://www.biomedcentral.com/1471-2458/11/486/prepub

\section{doi:10.1186/1471-2458-11-486}

Cite this article as: Silva et al.: Prevalence of non-communicable diseases in Brazilian children: follow-up at school age of two Brazilian birth cohorts of the 1990's. BMC Public Health 2011 11:486.

\section{Submit your next manuscript to BioMed Central and take full advantage of:}

- Convenient online submission

- Thorough peer review

- No space constraints or color figure charges

- Immediate publication on acceptance

- Inclusion in PubMed, CAS, Scopus and Google Scholar

- Research which is freely available for redistribution

Submit your manuscript at www.biomedcentral.com/submit
C Biomed Central 